\title{
Enhanced Surface Hardness of Commercially Pure Titanium by Pack Carburization with Rubberwood Charcoal and Rubberwood Ash
}

\author{
Natthaphong KONKHUNTHOT ${ }^{1,2}$, Patcharanut BURANAPIMA ${ }^{1}$, \\ Patipan BOONNITEE ${ }^{1}$, Mahamasuhaimi MASAE ${ }^{3}$ and Peerawas KONGSONG ${ }^{1, *}$
}

\author{
${ }^{I}$ Department of Materials Engineering, Faculty of Engineering and Architecture, Rajamangala \\ University of Technology Isan, Nakhon Ratchasima 30000, Thailand \\ ${ }^{2}$ RMUTI Institute of Aviation Industry, Rajamangala University of Technology Isan, \\ Nakhon Ratchasima 30000, Thailand \\ ${ }^{3}$ Department of Industrial Engineering, Faculty of Engineering, Rajamangala University of Technology \\ Srivijaya, Songkla 90000, Thailand
}

('Corresponding author’s e-mail: physics_psu@windowslive.com)

Received: 29 January 2021, Revised: 20 April 2021, Accepted: 26 April 2021

\begin{abstract}
In the present work, pack carburization with rubberwood charcoal and rubberwood ash at $925^{\circ} \mathrm{C}$ for 6,12 , and $24 \mathrm{~h}$ was carried out to improve the surface hardness of commercially pure titanium (CP-Ti). $\mathrm{X}$-ray diffraction and energy dispersive spectrometer analyses revealed the formation of titanium carbide (TiC) and the existence of oxygen diffusion in the carburized surface. The surface hardness of most optimized conditions has remarkably increased by $481 \%$ as compared to untreated CP-Ti (from $175 \mathrm{HV}$ to $1016 \mathrm{HV}$ ) due to the TiC surface layer, while the hardened oxygen diffusion layer of about $300 \mu \mathrm{m}$ indepth, as clearly seen in the microhardness profiles is useful for increased load-bearing capacity. Consequently, pack carburization with rubberwood charcoal and rubberwood ash is a promising surface modification technique, which can significantly enhance the surface hardness and increase the loadbearing capacity of CP-Ti for biomedical and tribological applications.
\end{abstract}

Keywords: Pack carburization, Rubberwood charcoal and ash, Surface hardness, CP-Ti, TiC

\section{Introduction}

Titanium alloys have gained considerable attention in a variety of engineering applications in aerospace, automotive, military, chemical, and biomedical industries due to their excellent strength to weight ratio, good corrosion resistance, and exceptional biocompatibility. The widespread use of titanium alloys in vivo implants and surgical equipment is feasible because of their dominant corrosion resistance and biocompatibility. Nevertheless, the inevitable limitation is their poor tribological properties, which eventually leads to high friction and wear, especially as they are applied for articulation joints. To extend their practical applications, surface modification techniques (e.g., ion implantation, physical and chemical vapor deposition, plasma carburizing, gas carburizing and nitriding process, and thermal spray) have been commonly employed to produce a cermet coating, which combines good properties of both toughness and hardness obtained from metal and ceramic for biomedical and tribological applications [1]. Among these is pack carburization, which is the potential method and regarded as the most widely used thermochemical treatment for enhanced surface hardness and improved wear and corrosion resistance of iron and steel [2-6], titanium-based alloys [7-9], and other alloys [10,11].

In pack carburization, solid carbon sources are charcoal or graphite powder, which are generally activated by carbonates "energizers" such as barium carbonate $\left(\mathrm{BaCO}_{3}\right)$, sodium carbonate $\left(\mathrm{Na}_{2} \mathrm{CO}_{3}\right)$, and 
calcium carbonate $\left(\mathrm{CaCO}_{3}\right)$. These carbonates will decompose thermally at high temperature into carbon dioxide $\left(\mathrm{CO}_{2}\right)$ and subsequently into carbon monoxide $(\mathrm{CO})$ to react with the titanium surface $[12,13]$. Pack carburization is a high-temperature surface chemical process that is associated with 2 steps: (i) the absorption and (ii) diffusion of atomic carbon into metal alloys, resulting in the metal carbides (MCs) formation on the surface. This is also considered the simplest and the most cost-effective surface modification techniques to generate $\mathrm{TiC}$ on titanium and its alloys. The outstanding properties of $\mathrm{TiC}$ include a high melting point $\left(3170{ }^{\circ} \mathrm{C}\right)$, low density, high hardness $(2500-3000 \mathrm{HV})$, superior chemical and thermal stability, and good wear resistance [1]. Moreover, it possesses a potential biocompatible carbide layer [14], which is a very important non-oxide ceramic widely used in the fields where hardness and wear resistance are required, for example, in biomedical and tribological applications. Many authors have reported that alkalis $(x=\mathrm{Na}, \mathrm{K}, \mathrm{Rb})[4,5]$ doped titanium dioxide has the potential as a material for environmental photocatalysis. Although some authors claim that the band gap of the solid is reduced due to a rigid valence band shift upon doping, others attribute the observed absorption of visible light by alkalis doped $\mathrm{TiO}_{2}$ to the excitation of electrons from localized impurity states in the band gap. Interestingly, it appears that the alkalis doping induced modifications of the electronic structure may be due to the penetration of alkali ions into $\mathrm{TiO}_{2}$ lattice, or they probably are bonded with oxygen onto $\mathrm{TiO}_{2}$ surface to form alkalis oxides. Both of the two factors restricted the growth of $\mathrm{TiO}_{2}$ nanocrystal [6].

In the recent years, the reduction and/or the recycling of agricultural wastes into useful materials play a special role with respect to engineering applications in biofuel, carbon, fiber, silica, lignin, etc [1520]. Previously, various attempts to develop an appropriate method in agricultural waste recycling for pack carburization have been studied. Thammachot et al. investigated the influences of an energizer by eggshells as well as carburizing temperature and time on the mechanical properties in pack carburization [21]. According to the results, they found that eggshells had more effect than commercial $\mathrm{CaCO}_{3}$ in increasing impact absorbed energy along with good surface hardness. Also, Masae et al. studied the preparation of rubberwood ash into calcium phosphate bio-ceramic powders by a simple sol-gel method [22]. They reported that the synthesized materials' crystal structure was mainly composed of $\mathrm{CaCO}_{3}$. Concerning these aspects, the use of rubberwood ash as a source of carbonaceous medium for pack carburization would be possible.

A rubberwood tree is a tropical hardwood and an economic crop in the family of the Pará rubber tree 'Hevea brasiliensis', which is abundantly planted in Southeast Asia. In Thailand, it accounts for approximately 217 million metric tons of the annual gross rubberwood ash of the annual gross waste [22]. However, the rubberwood tree has its own production cycle. It is generally harvested for about 30 years old before being cut down because of a low latex yield. Here, the consequent rubberwood tree is considered a kind of agricultural wastes, which is applicable as a solid carbon source for the pack carburization, as reported in the literature [23]. This promising material leads to further development and renewal of pack carburization, which is expected to be alternative materials sustaining environmentallyfriendly manufacturing in the future.

In the present study, pack carburization of the rubberwood charcoal and rubberwood ash were used as the carburizing and carbonaceous medium to enhance the surface hardness of the titanium substrates. The dependence of the compositional profiles as well as microstructural features and the surface hardness on the carburizing time was investigated experimentally. Surface characterization illustrated that pack carburization can considerably enhance the surface hardness and increase the load-bearing capacity of titanium due to the formation of the $\mathrm{TiC}$ and the hardened oxygen diffusion layer. Beneficial effects from this research are expected not only to replace commercially carburizing and carbonaceous medium but also to encourage economic diversification and add economic value to these wastes.

\section{Materials and methods}

\section{Sample preparation}

Commercially pure titanium (CP-Ti) grade 2 (99.4\% purity) plates were fabricated into a rectangular shape of $254 \times 254 \times 1 \mathrm{~mm}^{3}$ for the substrate materials. Before further experiments, all substrates were manually ground with silicon carbide (SiC) sandpaper down to 1200 grit, resulting in 
surface roughness $(\mathrm{Ra})$ of $20 \mathrm{~nm}$, and then ultrasonically cleaned in methanol for 15 min to obtain a flat and clean surface. After surface preparation, the specimens were treated using pack carburization with rubberwood charcoal and rubberwood ash. The homogeneous and fine carburizing compound was prepared through crushing and screening by a sieve pan No.10 ( $2 \mathrm{~mm}$ mesh size) before being mixed in a ratio of 9:1 (rubberwood charcoal: rubberwood ash (wt/wt)). CP-Ti specimens were placed in a steel container with an internal volume of $200 \mathrm{~cm}^{3}$ filled with the carburizing compound. The formation of titanium's surface oxides such as rutile $\left(\mathrm{TiO}_{2}\right)$ by oxidation at high temperature was restrained by sealing the container with heat resistant cement, creating a limited oxygen condition, as demonstrated in Figure 1. Once the sealing has done, the carburizing container was placed inside a muffle furnace and heated up with a heating rate of $5{ }^{\circ} \mathrm{C} / \mathrm{min}$ to the carburizing temperature of $925^{\circ} \mathrm{C}$ for soaking time of 6,12 , and 24 $\mathrm{h}$ before being cooled down with a cooling rate of $4{ }^{\circ} \mathrm{C} / \mathrm{min}$ to room temperature. After carburization, carburized specimens were slightly polished to remove any loosely deposited layers on the surface and subsequently were ground with $\mathrm{SiC}$ sandpaper from 240 to 1200 grit. This was followed by $0.05 \mu \mathrm{m}$ alumina paste polishing before being ultrasonically cleaned in methanol for $15 \mathrm{~min}$.

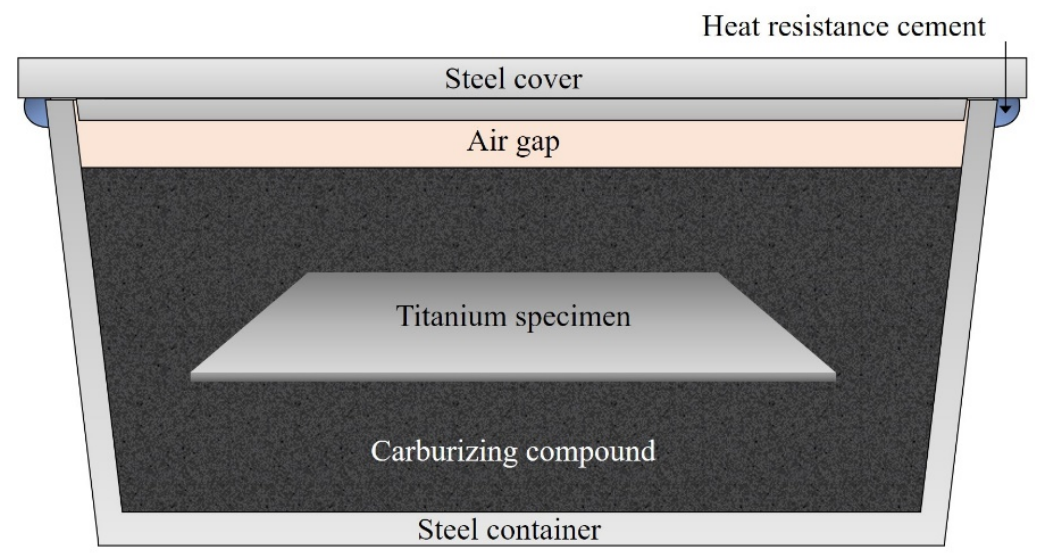

Figure 1 Schematic illustration of pack carburization.

\section{Surface characterizations}

The cross-section micrographs and compositional profiles were determined using a field emission scanning electron microscope (FESEM, JEOL, JSM) equipped with energy-dispersive X-ray spectroscopy (EDS). Surface microstructures of the carburized specimens were examined using X-ray diffraction (Shimadzu, XRD-6100) with a Cu-K $\alpha$ radiation source at $2.0 \mathrm{kV}$ and $30 \mathrm{~mA}$ in the $35^{\circ}-65^{\circ}$. The correlation of the surface hardness and depth was measured by micro Vickers hardness tester (Matsuzawa, MHT2) at an applied load of $1.96 \mathrm{~N}$ for a duration of $15 \mathrm{~s}$. At least 6 repeated indentations in each specimen were carried out to receive satisfactory statistical reliability and average values.

\section{Results and discussion}

\section{Surface morphological and elemental composition analysis}

The cross-sectional SEM micrographs of carburized specimens at $925^{\circ} \mathrm{C}$ for 6,12 , and $24 \mathrm{~h}$ were displayed in Figure 2. A dark layer can be observed at the outmost surface followed by a gray transition layer, which corresponds to the TiC layer and the network-structure of carbon- and oxygen-rich structure, as demonstrated by EDS and XRD analysis (Figures $\mathbf{3}$ and 4). From the cross-sectional SEM micrographs, the carburized layer adheres well to the titanium substrates, as can be observed with no 
peeling of the surface layer, which is due to a very small difference of density between TiC $\left(4.91 \mathrm{~g} / \mathrm{cm}^{3}\right)$ and $\mathrm{Ti}\left(4.51 \mathrm{~g} / \mathrm{cm}^{3}\right)$ [24] and the stabilized $\alpha$-titanium of interstitial solute (carbon and oxygen) $[25,26]$. This allows the formation of the TiC surface layer and the dissolution of carbon and oxygen into the titanium substrate to be the carbon- and oxygen-rich structure as given below.
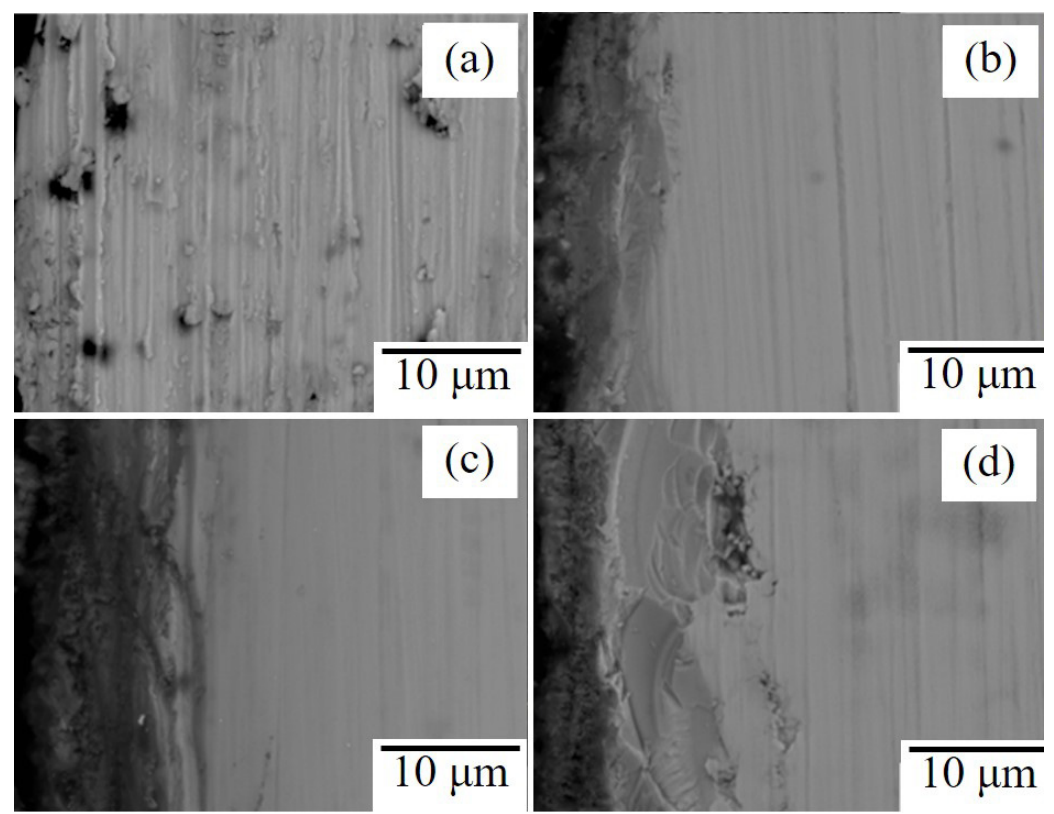

Figure 2 Cross-sectional SEM micrographs of (a) untreated CP-Ti, carburized specimens at $925{ }^{\circ} \mathrm{C}$ for (b) $6 \mathrm{~h}$, (c) $12 \mathrm{~h}$, and (d) $24 \mathrm{~h}$.

EDS mapping images (Figure 3) illustrate the distribution of carbon $(\mathrm{C})$, oxygen $(\mathrm{O})$, and titanium (Ti) of carburized specimens at $925^{\circ} \mathrm{C}$ for 6,12 , and $24 \mathrm{~h}$, respectively. The mapping images reveal the carbon-rich region at the surface and the distribution of oxygen through the $\alpha$-titanium substrates, consistent with the composition profiles identified by EDS line scanning (Figure 4). According to the composition profiles, the carbon concentration is relatively high at the surface and varies between $7-13$ $\mu \mathrm{m}$ depending on the carburizing time and then decreased into the titanium substrates with the depth. The oxygen is also detected to be slightly higher than carbon in the diffusion zone, indicating that the network structure in this zone is rich in oxygen. However, the carbon can diffuse and react with titanium to form a Ti-C solid solution [25] in the limited solid solution region because of not much difference in the atomic radius for carbon $(0.07 \mathrm{~nm})$ and titanium $(0.25 \mathrm{~nm})$ [27]. 


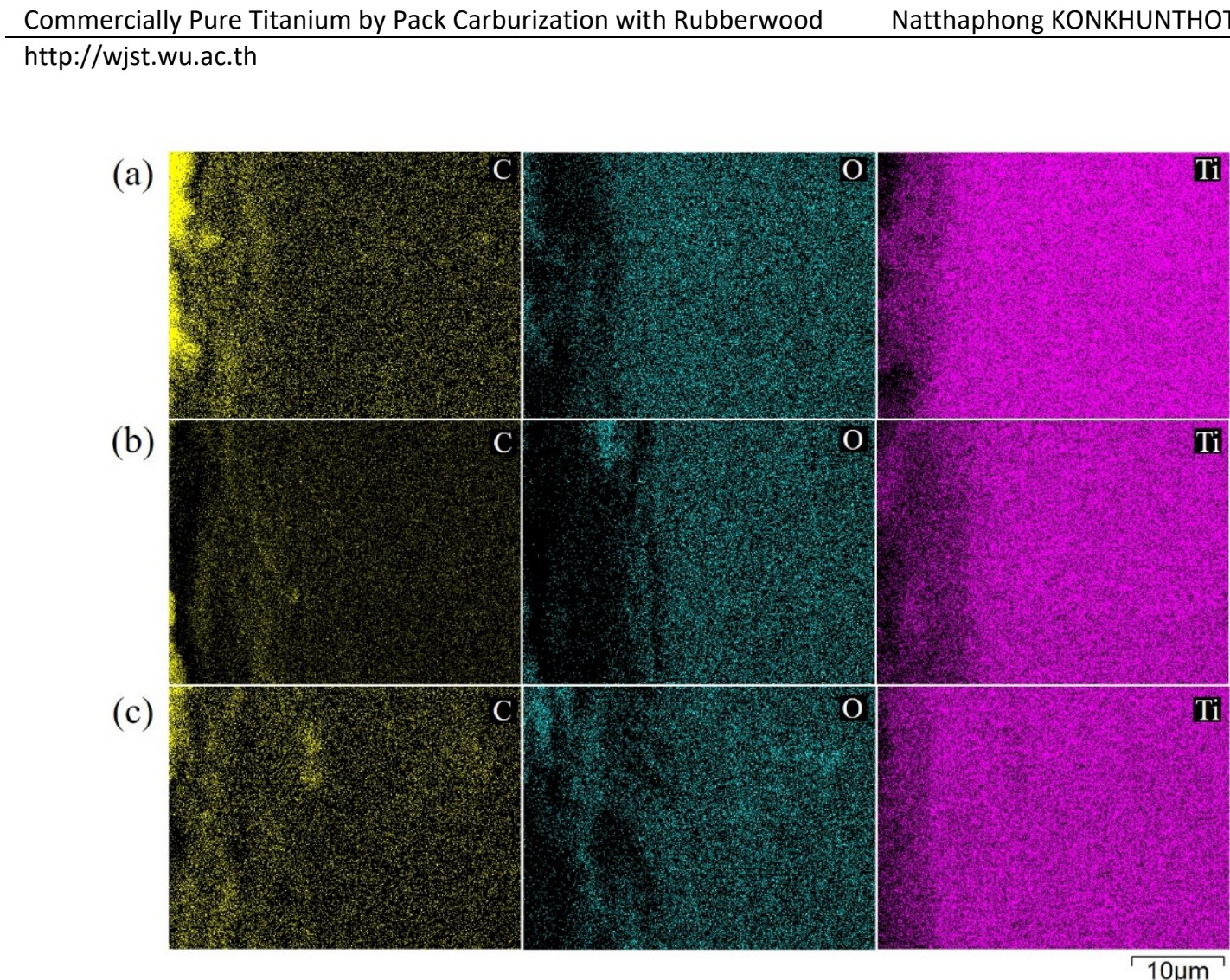

Figure 3 EDS mapping images of carburized specimens at $925^{\circ} \mathrm{C}$ for (a) $6 \mathrm{~h}$, (b) $12 \mathrm{~h}$, and (c) $24 \mathrm{~h}$. 

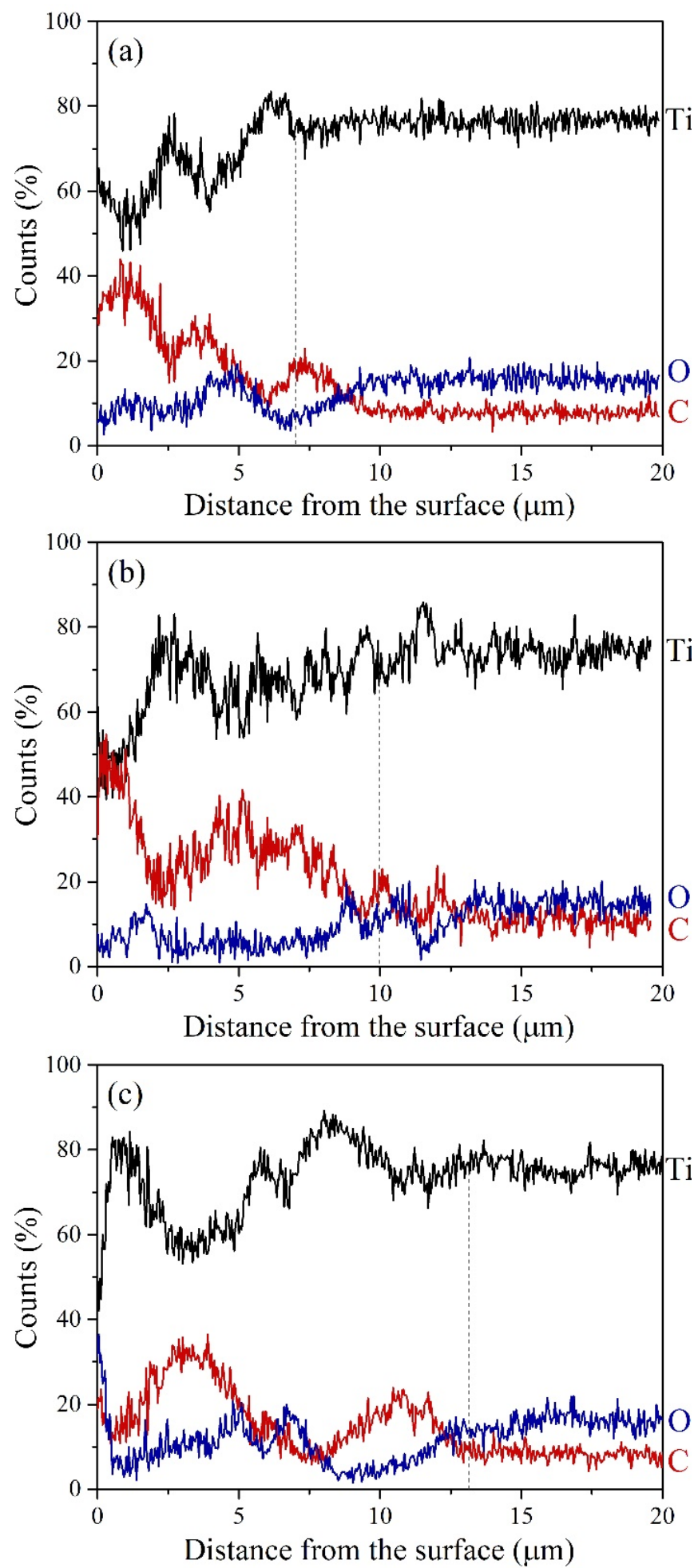

Figure 4 EDS line scanning of carburized specimens at $925^{\circ} \mathrm{C}$ for (a) $6 \mathrm{~h}$, (b) $12 \mathrm{~h}$, and (c) $24 \mathrm{~h}$. 


\section{Surface microstructural analysis}

The microstructures of untreated CP-Ti and carburized specimens at $925^{\circ} \mathrm{C}$ for 6,12 , and $24 \mathrm{~h}$ were examined by X-ray diffraction (XRD) as shown in Figure 5. According to the XRD examinations, diffraction peaks located at $35^{\circ}, 37^{\circ}, 40^{\circ}, 53^{\circ}$, and $63^{\circ}$ are consistent with the (100), (002), (101), (102), and (110) crystallographic plane, respectively, which is referred to the JCPDS-ICDD $44-1294$ standard for the close-packed hexagonal $\alpha$-titanium substrate. A peak located at $36^{\circ}$ is consistent with the (111) crystallographic plane, which is indexed according to the JCPDS $32-1383$ standard for a cubic structured TiC phase. The results indicate that pack carburization with rubberwood charcoal and ash is an effective method in the introduction of carbon atoms into the titanium substrate in the form of a TiC layer. $\mathrm{XRD}$ also reveals the existence of oxygen diffusion in the carburized specimens in the form of rutile $\left(\mathrm{TiO}_{2}\right)$ or might be any sub-oxides; for example, $\mathrm{TiO}, \mathrm{Ti}_{2} \mathrm{O}_{3}$, and $\mathrm{Ti}_{3} \mathrm{O}_{4}$, which are the complex structure to be distinguished difficultly [28]. The oxygen that is diffused in the $\alpha$-titanium matrix results in a slight shift in the $\alpha$-titanium peak toward a lower degree due to the distortion "expansion" of the lattice $[12,28$ 30]. In terms of the oxygen diffusion at a high temperature above $600{ }^{\circ} \mathrm{C}$, a thick scale of oxides can expand rapidly by oxidation [12,31-33]. After a prolonged carburization, oxygen diffuses from their oxides to further depth into the oxygen diffusion layer, as obviously seen by EDS line scanning. At the same time as the surface oxide decreases, $\mathrm{TiC}$ starts to form at the surface when $\mathrm{CO}$ reaches levels for carburization. The oxygen diffusion layer plays a major role in increasing the deep case-hardening of carburized titanium, which will be further discussed in the following section.

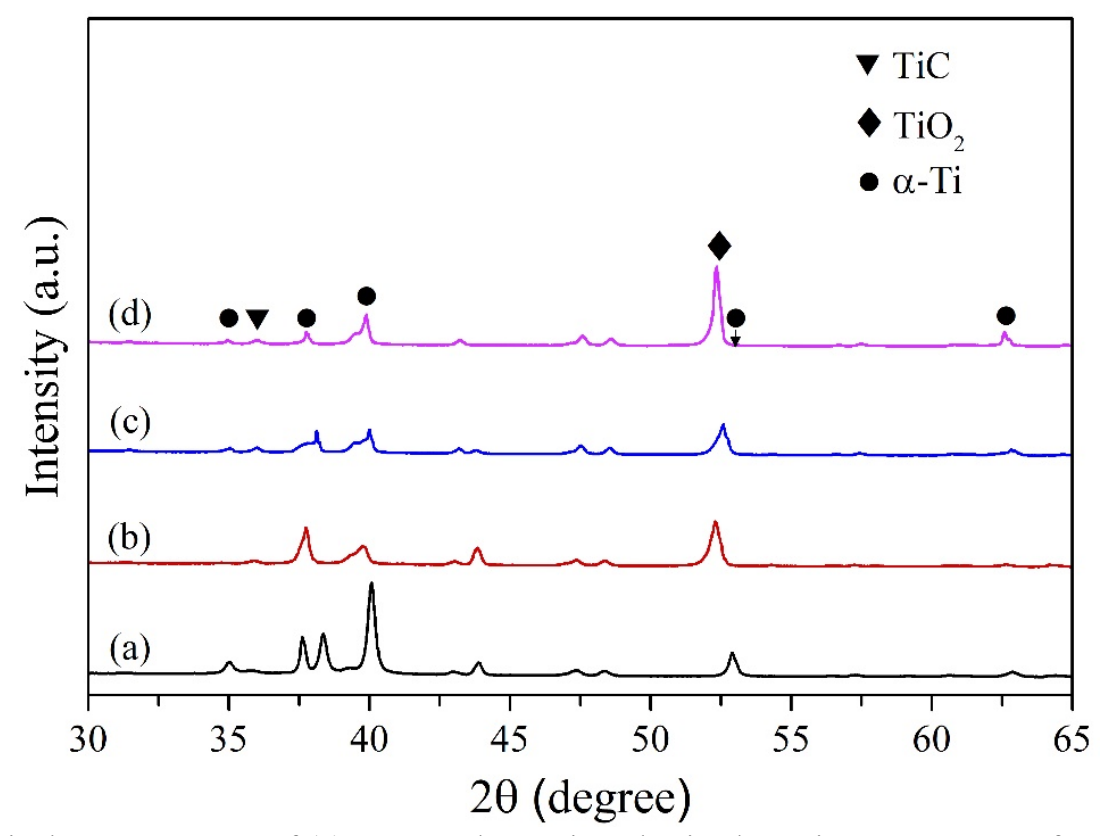

Figure 5 Typical XRD patterns of (a) untreated CP-Ti, carburized specimens at $925{ }^{\circ} \mathrm{C}$ for (b) $6 \mathrm{~h}$, (c) 12 h, and (d) $24 \mathrm{~h}$.

\section{Surface hardness investigation}

Micro Vickers hardness test was performed to measure the hardness depth profiles of untreated CP$\mathrm{Ti}$ and carburized specimens at $925^{\circ} \mathrm{C}$ for 6, 12, and $24 \mathrm{~h}$. Microhardness results (Figure 6) demonstrate that the hardness depth profile of untreated CP-Ti is rather constant at about $175 \mathrm{HV}$ through the whole depth. Conversely, the hardness near the surface is significantly high at 792, 828, and $1016 \mathrm{HV}$ for carburized specimens at $925{ }^{\circ} \mathrm{C}$ for 6,12 , and $24 \mathrm{~h}$, respectively. Regarding the specimen that is 
carburized at $925^{\circ} \mathrm{C}$ for $24 \mathrm{~h}$ (the optimized carburizing condition), it shows the highest surface hardness with a great increase by $481 \%$ from $175 \mathrm{HV}$ to $1016 \mathrm{HV}$. An exceptional hardness for carburized specimens is attributed to the presence of the TiC layer varying in the range of $7-13 \mu \mathrm{m}[13,34]$, while the hardness gradient of carburized specimens is mainly due to a reduction in the amount of TiC. However, besides the hardness of the TiC layer, an extensive hardened layer of about $300 \mu \mathrm{m}$ in-depth is observed to have benefit for the carburized specimens as well. The hardened layer is considered as the oxygen diffusion layer because oxygen is detected more than carbon in the diffusion zone, as demonstrated by the EDS line scans (Figure 4). Oxygen is an interstitial element, which plays an important effect on solid solution strengthening in titanium [28]. Theoretically, since the atomic radius of oxygen $(0.05 \mathrm{~nm})$ is much less than that of titanium $(0.25 \mathrm{~nm})$ [27], the oxygen atoms that diffuse into titanium will be embedded in interstitial sites of titanium's crystal structure. This has led to the distorted crystal structure, as observed by a shift in the $\alpha$-titanium peak toward a lower degree, resulting in impeding the dislocations' mobility. Hence, it is needed more force "energy" to move the dislocations, making titanium strengthener.

According to microhardness results, pack carburization with rubberwood charcoal and rubberwood ash on titanium substrates can effectively enhance the mechanical properties in terms of much-enhanced surface hardness due to the formation of the TiC surface layer of about $7-13 \mu \mathrm{m}$. Additionally, an extensive hardened "oxygen diffusion" layer of about $300 \mu \mathrm{m}$ is useful for improved load-bearing and anti-wear capacity for tribological applications as previously reported by Bailey and Sun [12].

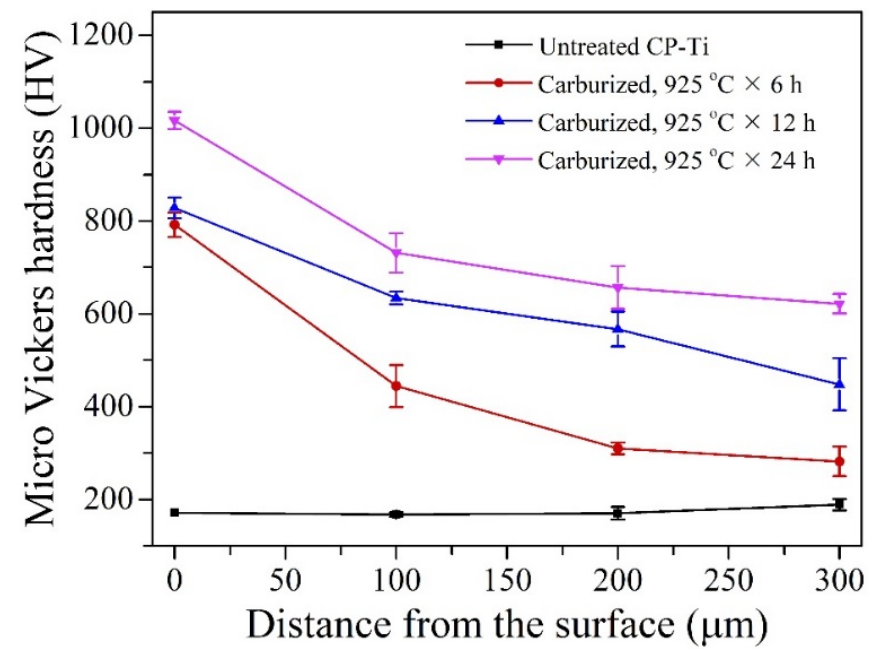

Figure 6 Correlation of the micro Vickers hardness on the depth of untreated CP-Ti, carburized at $925{ }^{\circ} \mathrm{C}$ for $6 \mathrm{~h}, 12 \mathrm{~h}$, and $24 \mathrm{~h}$, respectively.

\section{Conclusions}

In this study, the authors proposed pack carburization to enhance the surface hardness of CP-Ti specimens by adopting rubberwood charcoal and rubberwood ash as a carburizing and carbonaceous medium generating active carbon atoms. The compositional profiles and microstructures, and surface hardness were systematically investigated in correlation with the carburizing time. The meaningful results can be summarized as follows:

(1) The cross-sectional SEM micrographs illustrate that the carburized layer adheres well to titanium substrates with no peeling of the surface.

(2) EDS line scanning reveals the carbon concentration that is relatively high at the surface and varies in the range of $7-13 \mu \mathrm{m}$ depends upon the carburizing time. The slightly higher oxygen can be 
detected and mainly found in the diffusion zone, which indicates oxygen-rich structure in this zone due to a strong $\alpha$-titanium stabilizer and an interstitial element of oxygen.

(3) The TiC formation and the existence of oxygen diffusion in the form of rutile (TiO2) in carburized specimens are confirmed by the XRD examination.

(4) The surface hardness significantly enhances by $481 \%$ (from $175 \mathrm{HV}$ to $1016 \mathrm{HV}$ ) compared with that of untreated $\mathrm{CP}-\mathrm{Ti}$, mainly due to the formation of the $\mathrm{TiC}$ surface layer. The hardened oxygen diffusion layer of about $300 \mu \mathrm{m}$ in-depth is considered useful for the increased load-bearing capacity of carburized titanium.

Finally, we debate that this carburization using the rubberwood charcoal and rubberwood ash would be a potential method applicable to enhance surface hardness and improve the load-bearing capacity required for biomedical and tribological applications.

\section{Acknowledgements}

The authors are grateful to the Department of Materials Engineering, Faculty of Engineering and Architecture of the Rajamangala University of Technology Isan, Thailand for supporting this work. We also wish to acknowledge the assistance of Ms. Martha Maloi Eromine at the Research \& Publication Clinic of the Institute of Research and Development at the Rajamangala University of Technology Isan for English proofreading.

\section{References}

[1] DB Lewis, A Leyland, PR Stevenson, J Cawley and A Matthews. Metallurgical study of lowtemperature plasma carbon diffusion treatments for stainless steels. Surf. Coat. Technol. 1993; 60, 416-23.

[2] KT Rie. Recent advances in plasma diffusion processes. Surf. Coat. Technol. 1999; 112, 56-62.

[3] M Egawa, N Ueda, K Nakata, M Tsujikawa and M Tanaka. Effect of additive alloying element on plasma nitriding and carburizing behavior for austenitic stainless steels. Surf. Coat. Technol. 2010; 205, 246-51.

[4] CJ Scheuer, RP Cardoso, FI Zanetti, T Amaral and F Brunatto. Low-temperature plasma carburizing of AISI 420 martensitic stainless steel: Influence of gas mixture and gas flow rate. Surf. Coat. Technol. 2012; 206, 5085-90.

[5] Y Wei, Z Zurecki and RD Sisson. Optimization of processing conditions in plasma activated nitrogen-hydrocarbon carburizing. Surf. Coat. Technol. 2015; 272, 190-7.

[6] N Tsuji, S Tanaka and T Takasugi. Evaluation of surface-modified Ti-6Al-4V alloy by combination of plasma-carburizing and deep-rolling. Mater. Sci. Eng. A 2008; 488, 139-45.

[7] N Tsuji, S Tanaka and T Takasugi. Effects of combined plasma-carburizing and shot peening on fatigue and wear properties of Ti-6Al-4V alloy. Surf. Coat. Technol. 2009; 203, 1400-5.

[8] X Yazhe, J Chaoping and H Jianmin. Surface strengthening of Ti-6Al-4V alloy by grow plasma carbonization process. Rare Metal Mat. Eng. 2013; 42, 1101-4.

[9] Y Kaneno, N Matsumoto, N Tsuji, S Tanaka and T Takasugi. Plasma-assisted surface hardening of dual two-phase intermetallic alloy composed of $\mathrm{Ni}_{3} \mathrm{X}$ type structures. Mater Sci. Eng. A 2009; 516, 84-9.

[10] H Han, S Baba, H Kitagawa, SA Sulil, K Hasezaki, T Kato, K Arakawa and Y Noda. Plasmacarburization of nickel-based self-fluxing alloy. Vacuum 2005; 78, 27-32.

[11] R Bailey and Y Sun. Pack carburisation of commercially pure titanium with limited oxygen diffusion for improved tribological properties. Surf. Coat. Technol. 2015; 261, 28-34.

[12] R Bailey and Y Sun. Corrosion and tribocorrosion performance of pack-carburized. commercially pure titanium with limited oxygen diffusion in a $0.9 \% \mathrm{NaCl}$ solution. J. Bio-Tribo-Corros. 2018; 4, $1-12$.

[13] PV Bharathy, D Nataraj, PK Chu, H Wang, Q Yang, MS RN Kiran, JS Albero and D Mangalaraj. Effect of titanium incorporation on the structural, mechanical and biocompatible properties of DLC 
thin films prepared by reactive-biased target ion beam deposition method. Appl. Surf. Sci. 2010; 257, 143-50.

[14] CM Liu and SY Wu. From biomass waste to biofuels and biomaterial building blocks. Renew Energ. 2016; 96, 1056-62.

[15] AD Adepoju, JA Adebisi, JK Odusote, II Ahmed and SB Hassan. Preparation of Silica from Cassava Periderm. J. Solid Waste Technol. Manag. 2016; 42, 216-21.

[16] VS Aigbodion, SB Hassan and JO Agunsoye. Effect of bagasse ash reinforcement on dry sliding wear behaviour of polymer matrix composites. Mater. Des. 2012; 33, 322-7.

[17] S Gu, J Zhou, Z Luo, Q Wang and Z Shi. Kinetic study on the preparation of silica from rice husk under various pretreatments. J. Therm. Anal. Calorim. 2015; 119, 2159-69.

[18] S Venkateswaran, R Yuvakkumar and V Rajendran. Nano silicon from nano silica using natural resource (Rha) for solar cell fabrication. Phosphorus sulfur Silicon Relat Elem. 2012; 188, 1178-93.

[19] EC Achinivu, RM Howard, G Li, H Graczb and WA Henderson. Lignin extraction from biomass with protic ionic liquids. Green Chem. 2014; 16, 1114-9.

[20] N Thammachot, P Nachaisit, W Homjabok, C Peeratatsuwan, A Mayai and J Nithikarnjanatharn. The effects of energizer and carburizing temperature and time on mechanical properties of hardened big knives in the pack carburizing process. KKU. Eng. J. 2016; 43, 172-7.

[21] M Masae, W Sririkun, P Kongsong and A Jeenarong. Preparation calcium phosphate bioceramic powders from rubber wood ash. Int. J. Innov. Sci. Eng. Technol. 2016; 3, 226-31.

[22] M Masae, L Sikong, P Kongsong, P Phoempoon, S Rawangwong and W Sririkun. Application of rubber wood ash for removal nickel and copper from aqueous solution. Environ Nat. Resour. J. 2013; 11, 17-27.

[23] BJ Choi, IY Kim, YZ Lee and YJ Kim. Microstructure and friction/wear behavior of $(\mathrm{TiB}+\mathrm{TiC})$ particulate-reinforced titanium matrix composites. Wear 2014; 318, 68-77.

[24] XY Liu, PK Chu and CX Ding. Surface modification of titanium, titanium alloys, and related materials for biomedical applications. Mater. Sci. Eng. R. 2004; 47, 49-121.

[25] Y Oshida. Bioscience and Bioengineering of Titanium Materials. Elsevier, USA, 2013, p. 9-34.

[26] DC Ghosh and R Biswas. Theoretical Calculation of Absolute Radii of Atoms and Ions. Part 1. The Atomic Radii. Int. J. Mol. Sci. 2002; 3, 87-113.

[27] ZX Zhang, H Dong, T Bell and B Xu. The effect of treatment condition on boost diffusion of thermally oxidised titanium alloy, J. Alloy Compd. 2007; 431, 93-9.

[28] H Dong and XY Li. Oxygen boost diffusion for the deep-case hardening of titanium alloys. Mater. Sci. Eng. A. 2000; 280, 303-10.

[29] F Omidbakhsh, AR Ebrahimi, SH Mousavi, RA Khosroshahi and S Nazarpour. Effect of oxygen boost diffusion treatment on fatigue behavior of Ti-4Al-2V alloy. Surf. Coat. Technol. 2011; 205, 2954-63.

[30] S Kumar, TS Narayanan, SG Raman and SK Seshadri. Evaluation of fretting corrosion behaviour of CP-Ti for orthopaedic implant applications. Tribol. Int. 2010; 43, 1245-52.

[31] M Jamesh, TS NS Narayanan and PK Chu. Thermal oxidation of titanium: Evaluation of corrosion resistance as a function of cooling rate. Mater. Chem. Phys. 2013; 138, 565-72.

[32] AR Shankar, NS Karthiselva and UK Mudali. Thermal oxidation of titanium to improve corrosion resistance in boiling nitric acid medium. Surf. Coat. Technol. 2013; 235, 45-53.

[33] Y Luo, S Ge, H Liu and Z Jin. Microstructure analysis and wear behavior of titanium cermet femoral head with hard TiC layer. J. Biomech. 2009; 42, 2708-11. 